\title{
2018 Presidential Elections and fertility variations across regions in Brazil
}

Everton E. C. Lima ${ }^{1}$ and José H. C. Monteiro da Silva ${ }^{2}$

\begin{abstract}
In this work, we analyzed the spatial distribution of fertility levels in 558 microregions of Brazil and correlated it with vote outcomes from the last presidential election of 2018, controlling for important confounding variables. Applying spatial regression models, to the contrary of expected, we see that votes in Bolsonaro did not associate positively with fertility levels. In fact, in regions where its political adversary won, the Brazilian Labour Party (PT), the fertility levels are on average higher than the ones where Bolsonaro had electoral success. However, we would expect that these results will be different, due to the fact that Bolsonaro represents conservatism and traditional family values, which in turn resumes in desires for more children. In line with McDonald's gender equity theory, we argue that votes in Bolsonaro may actually indicate other facets of reproduction, like an electorate with defending lesser gender equity in family institutions and that also configures in smaller TFR as consequence.
\end{abstract}

Keywords: Fertility, Electoral results 2018, Gender Equity

\footnotetext{
${ }^{1}$ Associate Professor at the College of Philosophy and Human Sciences (IFCH) at University of Campinas (UNICAMP) and research scientist at the Population. Studies Center (NEPO), everton.emanuel@gmail.com and/or evertone@unicamp.br.

${ }^{2}$ Consulting researcher at Economic Commission for Latin America and the Caribbean (ECLAC).
} 


\section{Introduction}

On 28 October 2018, Brazilian electorate delivered a victory to presidential candidate Jair Bolsonaro from the PSL party. Elected with 57.8 million votes, he brought to the table a far-right populist agenda to the world's fourth-largest democracy (Hunter and Power 2019; Chaga-Bastos 2019). During his campaign, the former army captain usually demonized his political opponents and promised to save the country from its economic and social ruin.

Until his election Brazil has shown extreme setbacks in terms of socioeconomic developments (Chaga-Bastos 2019). For instance, according to the National Statistics Office (IBGE 2019), until the presidential elections of 201812.9 million people were unemployed, and 27.5 million were considered 'underutilized labour force'. Moreover, 37.3 million workers were in the informal market with no labour protection or social insurance. Additionally, violence has considerably increased in the country, the Institute of Applied Economic Research (IPEA 2018) and the Brazilian Public Security Forum (FBSP 2018) indicates that the country is the world leader in homicides with 63,380 per year. This means 30.8 homicides per 100,000 inhabitants, more than three times the world's average.

Pleading a political agenda that efforts struggled to political corruption and economic revival through liberal approach, Bolsonaro defeated the left-leaning Workers' Party (PT), which had governed Brazil from 2003 to 2016 (Hunter and Power 2019). His political success can be attributed to extensive social media appeal, along with networks of Pentecostal churches and other religions groups, helped to disseminate Bolsonaro's messages and organize his political electorate (Dias 2019; Almeida 2019; Hunter and Power 2019).

There is an extensive demographic literature that analyzes the relationship between fertility and electoral outcomes. Pioneer in these studies, Lesthaeghe has shown that votes for secular parties (Socialist+Liberal), between the period 1880-1910, had a strong negative relationship with fertility across Belgian arrondissements, (Lesthaeghe 1977). Further study in the US has shown that election results in 2008 points to differences in voters' styles captured by the characteristics of the second demographic transition that predicts low fertility in contemporary societies (Lesthaeghe and Neidert 2009).

Inspired by these analyses, in Brazil, a historical study conducted by Lima (2010) aimed to understand the effects of the bi-party system, established in 1966 and extended until 1979, on fertility levels of municipalities of the country. The results of his study indicated that there was a clear distinction between voters of the Aliança Renovadora Nacional (ARENA) and the Movimento 
Democrático Brasileiro (MDB) in terms of small family size preferences, as seeing that in areas where this last party had majority of the votes the fertility levels were on average lower than the places that ARENA won the electoral election. As an extension to this study, in this work, we sought to understand if the electoral outcomes of the 2018 presidential election are also correlated with distinguished fertility levels in small areas of the country. Given the conservative political agenda (pro family) of the candidate from the Social Liberal Party (PSL), Bolsonaro, and how well polarized Brazilian electorate became, we believe that votes in the last election could be an interesting predictor of country fertility levels.

\section{Data and Methods}

We use micro censuses data from 2010 and electoral results of presidential first round elections in 2018, collected by the IPEADATA (http://www.ipeadata.gov.br/Default.aspx). Census provide the socioeconomic and reproductive information that we use to understand the factors associated with spatial fertility variations, and IPEADATA collects many information on economic and financial data for Brazil in annual, monthly and daily series in the same currency; demographic and geographic information for Brazilian states, municipalities (and their comparable areas) and administrative regions; and data and indicators on income distribution, poverty, education, health, social security and public security. Elections results are also compiled by this source and provided in many years and at municipality level.

We compute Total Fertility Rates (TFR) for 558 microregions of Brazil, by applying Hauer and Schmertmann (2018-2020) method to generate indirect estimates of fertility. The method uses census counts of population by age and sex. The foundation of our approach is the relationship between the number of young children in a population, the overall fertility level, child mortality, and relative fertility by age (Hauer and Schmertmann 2018).

We use Hauer and Schmertmann (2020) extended TFR approach, which is based on coefficients to adjust for non-uniform distributions of women across reproductive ages and generates robust results for subnational fertility estimation. TFR is given by equation 1, using the proportion of women aged 25 to 34 years old among women aged 15 to 49 years old $\left(P_{25-34}\right)$, the total number of women aged 15 to 49 years old (W) and the total number of children aged 0 to 4 years old (C) :

$$
T F R=\left(10.65-12.55 * P_{25-34}\right) \times C / W
$$

We tested the hypothesis that vote in Bolsonaro (PSL party) is associated with higher fertility levels, and we control it for a number of well studied covariates and that affects fertility (Potter et al 
2002; Beaujouan et al. 2013; Berquó and Cavenaghi 2014), degree of microregion urbanization (population size of area), proportion of women at reproductive risk, cash transfer program (Bolsa Família), proportion of population in the microregion with complete secondary education, the proportion of filiations with Pentecostal religion and the old-age dependency ratio. Additionally, we also correlate fertility with null and blank vote, and we introduce spatial controls, considering the geographic coordinates (latitude and longitude) of each microregion.

The electoral outcome considered refers to first round ballot results; we believe that this better captured the real ideological voters of each party, which may reflect in behaviors that affect couples reproductive decision. An additional word of caution is also needed, because the votes refer to 2018 and the fertility estimates indicate an past average TFR over the five-year period and not precise the census year of 2010. This temporal lag should not be put aside in the interpretations.

\section{Results}

In the following maps of Figure 1, we present the spatial distribution of the first round share percentage of votes for the Workers Party (PT) and Social Liberal Party (PSL). As we can see, for both parties the votes percentages are completely opposite in terms of spatial location, with PT being relatively strong in the Northeastern and Northern areas of the country, as the PSL dominates the political scenario in the next three great regions of Brazil, Southeast, South and Midwest.

Figure 1: Percentage share of votes presidential elections of 2018 Brazil, votes for PT vs. PSL.

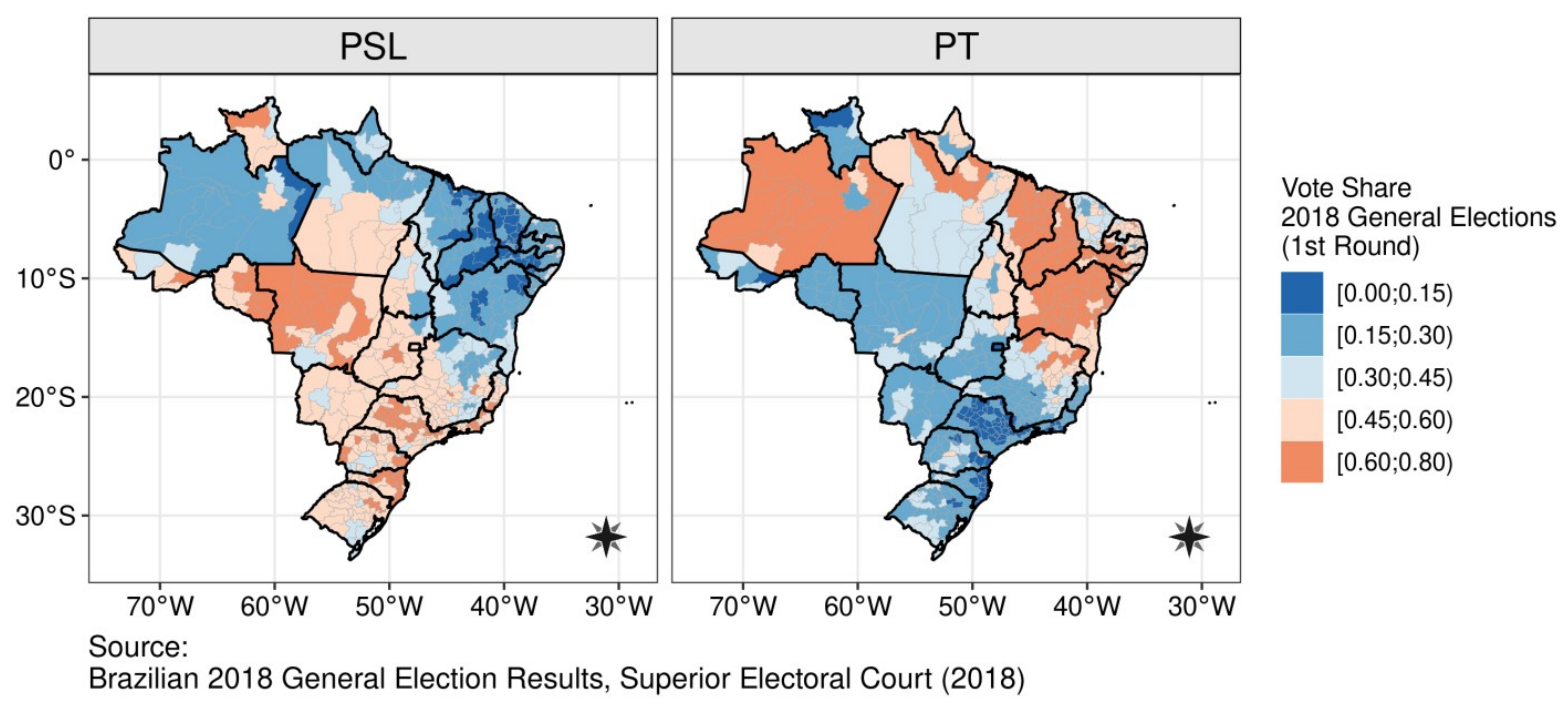


We can also try to see if this electoral schism can be translated into different associations with TFRs. That is verified in Figure 2, for our surprise the relationship between fertility and PSL votes are not positively associated with fertility, and the contrary can also be said to vote for the Workers Party (PT), which shows positive association with fertility. This contradicts our initial hypothesis that expected higher fertility in areas where Bolsonaro had the majority of votes. However, the PSL candidate had also strong electoral support in more developed socioeconomic locations of Brazil and this may explain this negative association with TFR.

Figure 2: Electoral shared percentage of votes PSL and PT versus TFRs, Brazil 2010-2018.

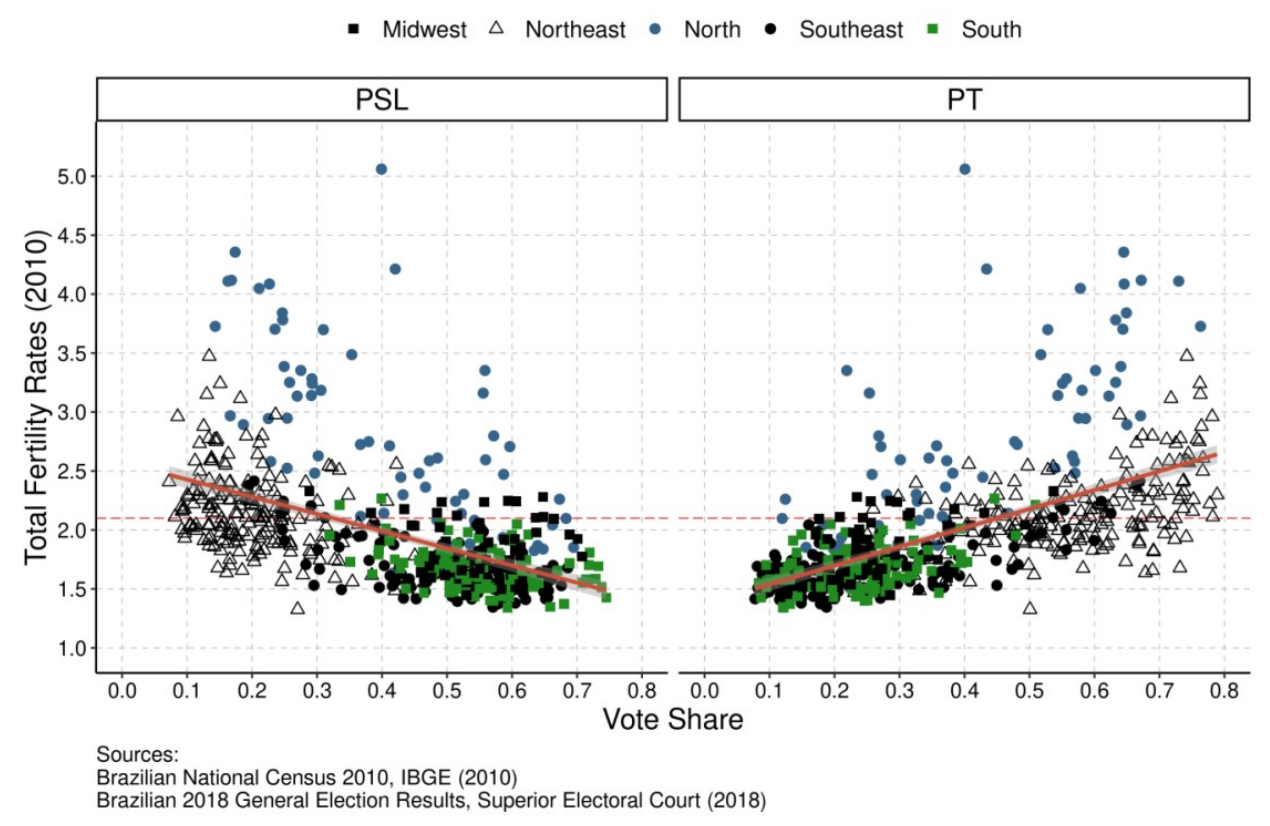

Another way to explore these results is through a bivariate map that correlates the variables, TFR and PSL votes, in a single figure. In Figure 3 we see that almost the whole North and Northeast of Brazil are dominated by high fertility and low voters for the PSL party.

In the Midwest region, however, there is a mix of isolated clustered regions with high percentage voters for PSL with medium to high fertility levels, and other combinations of these two variables are also noticed in certain areas, but there is no clear spatial pattern observed. These isolated hotspots areas of high fertility and votes for Bolsonaro are still few and mostly concentrated in the Midwest and also at certain parts in the Northern of Brazil. 
Figure 3: Bivariate maps of fertility and PSL percentage share in Brazil 2010-2018.

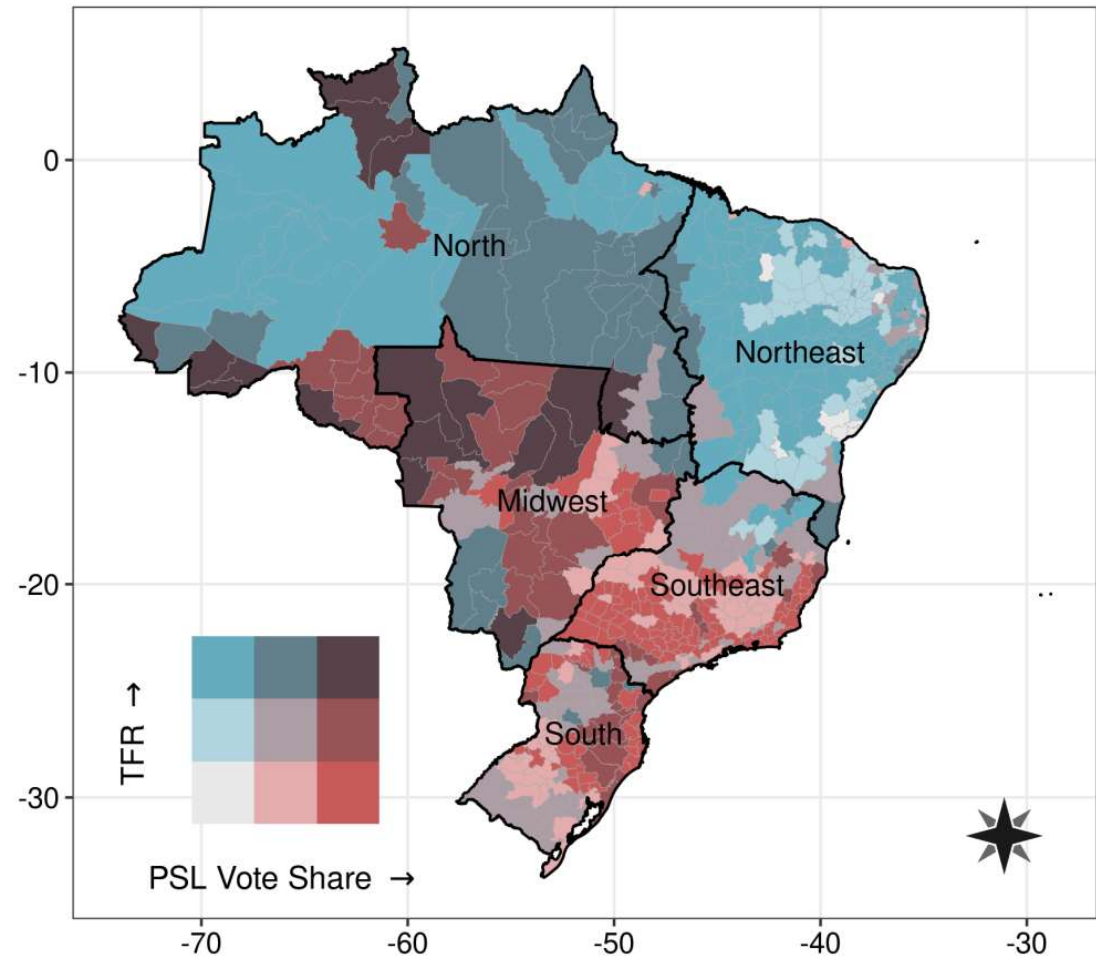

Sources:

Brazilian National Census 2010, IBGE (2010)

Brazilian 2018 General Election Results, Superior Electoral Court (2018)

In the most developed South and Southeast regions of the country, there is in general a combination of high percentage of Bolsonaro electorate and low fertility levels among the microregions. This is somehow expected as Bolsonaro led the vote ballots in these two great areas, and in his campaign the liberal economic discourse fitted with the entrepreneurship and business oriented population in these regions (Hunter and Power 2019).

In fact, when it comes to fertility, the Bolsonaro electorate is divided into two antagonist groups. From one side, there are the Pentecostal religious groups with traditional and conservative beliefs that generally translate in higher fertility levels (Lima et al 2019). But, on the other side, there are also these elite business oriented people from high socioeconomic status, and these generally have lower fertility. We will test this complex relationship in the following spatial regression models in Table 1.

In table 1, we summarize the estimates for the TFRs in function of three groups of control variables, electoral, socioeconomic and demographic and spatial variables. We have built the models in blocks, first, we just control for electoral results and population size of the microregion. In the 
second model, we introduce all socioeconomic and demographic variables; and as last model we have all covariates as control together with the spatial variables, indicating the locations of each microregion (this is the spatial trend or large scale spatial control) and autoregressive model controlling for the neighborhood influence (this is spatial autocorrelation or small scale spatial control).

Table 1: Regression models of TFR in function of socioeconomic, spatial and electoral variables in Brazil, 2010-2018.

\begin{tabular}{|c|c|c|c|c|c|c|}
\hline \multirow{2}{*}{ Variable and models } & \multicolumn{2}{|c|}{ Model 1} & \multicolumn{2}{|c|}{ Model 2} & \multicolumn{2}{|c|}{ Model 3} \\
\hline & $\boldsymbol{\beta}$ & P-value & $\boldsymbol{\beta}$ & P-value & $\boldsymbol{\beta}$ & P-value \\
\hline Intercept & 3.285 & 0.0000 & 3.166 & 0.0000 & 1.872 & 0.0000 \\
\hline $\begin{array}{l}\text { Proportion of votes to PSL president } \\
\text { candidate in } 2018\end{array}$ & -1.059 & 0.0000 & -0.138 & 0.4399 & -0.957 & 0.0000 \\
\hline Proportion of blank votes in 2018 & -24.645 & 0.0000 & -5.387 & 0.0054 & -4.473 & 0.0318 \\
\hline Proportion of null votes in 2018 & -4.552 & 0.0000 & -4.431 & 0.0000 & -0.154 & 0.8529 \\
\hline Population size of the area in 2010 & -0.046 & 0.0104 & -0.007 & 0.6030 & -0.013 & 0.1710 \\
\hline $\begin{array}{l}\text { Proportion of households benefited from } \\
\text { cash transfer program 'Bolsa Familia' in } \\
2010\end{array}$ & & & 1.700 & 0.0000 & 1.152 & 0.0000 \\
\hline $\begin{array}{l}\text { Proportion of women with complete } \\
\text { secondary education in } 2010\end{array}$ & & & -2.665 & 0.0000 & -2.424 & 0.0000 \\
\hline $\begin{array}{l}\text { Proportion of population affiliated to } \\
\text { Pentecostal churches in } 2010\end{array}$ & & & 1.355 & 0.0000 & 0.345 & 0.2194 \\
\hline Old-Age Dependency Ratio in 2010 & & & -6.570 & 0.0000 & -4.421 & 0.0000 \\
\hline Longitude & & & & & -0.033 & 0.0000 \\
\hline Latitude & & & & & 0.012 & 0.0005 \\
\hline $\mathbf{R}^{2}$ & & & & & & \\
\hline
\end{tabular}

Model 1: vote and population control variables (general controls).

Model 2: general controls + socio-demographic controls.

Model 3: spatial simultaneous autoregressive error model estimation, model 2 controls + spatial controls (large and small scale controls). Spatial autocorrelation test -210.46 , p-value $<0.00000$.

Note: criteria of variables selection is based of Variance Inflation Factor.

In our findings, most socioeconomic variables indicate expected association with microregion TFRs. For instance, more percentage of women with secondary education living in the microregion indicated lesser fertility levels. A high proportion of households in the microregion receiving the cash transfer program (Bolsa Familia) represent a positive association with reproduction. In 
addition, the proportion of Pentecostal people living in the microregion is positively associated with TFR, but this effect lost predictive power in the complete model 3.

The spatial trend captured by the geographical coordinates is also important to explain microregions fertility variations. Negative sign in beta coefficient for longitude indicates that if we move to the coast side of the country fertility will be lower. The latitude coordinate indicates another direction, which is a positive association with fertility, e.g. going to the Northern parts of the country we will find higher fertility levels.

The electoral variables also are presenting appealing relationships with fertility levels of the areas. A higher proportion of blank votes indicate almost 5 times lower fertility in the microregion, the null vote has also a negative association with TFR, but on a smaller scale. The most intriguing electoral result is the persistent negative relationship between votes for the PSL president candidate and fertility, and that is observed in all estimated models.

In fact, these results need to be evaluated carefully, because the TFR represents a period before the actually electoral outcomes took place in 2018. Hence, we are trying to associate past fertility experiences with eight years later votes. One could argue that the desirable is to estimate microregion fertility in the year 2018 and associate that with PSL results for the same year, or a close date.

Unfortunately, the available birth data from civil registers and Ministry of health in Brazil lacks of quality, especially in more disaggregated levels (Lima et al 2018), and that will compromise the models as North and Northeast regions present higher number under-registration of birth counts, which in turn will reflect in possible wrong associations. In addition, the exposed population for the fertility rates estimates comes only from census' years. Non-censuses years' population is forecasted by the National Statistics Office of Brazil, thus even if use the same Hauer and Schmertmann (2020), we will be stuck with the problem of a circular logic: TFR forecast -> expected age pyramid -> TFR estimate.

As way to overcome this problem, we will invert the causality order and estimate the same models, but this time considering PSL votes in 2018 as response variable. This way, we have the following order of facts: TFR in 2010 predicts PSL votes in 2018, which makes more sense chronologically. These models are presented in Table 2 .

If we maintain our attention only in the association between TFR and PSL vote (see the complete model 3 in table 2), again the same negative relationship between the two variables is observed, which reinforces our previous results. It seems that 2010 spatial fertility configuration in the 
country somehow is observed in the electoral outcomes of the presidential elections some years later.

Table 2: Regression models of PSL vote share in function of TFR, socioeconomic, spatial and electoral variables in Brazil, 2010-2018.

\begin{tabular}{|c|c|c|c|c|c|c|}
\hline \multirow{2}{*}{ Variable and models } & \multicolumn{2}{|c|}{ Model 1} & \multicolumn{2}{|c|}{ Model 2} & \multicolumn{2}{|c|}{ Model 3} \\
\hline & $\beta$ & P-value & B & P-value & $\beta$ & P-value \\
\hline Intercept & 0.821 & 0.0000 & 0.820 & 0.0000 & 0.445 & 0.0000 \\
\hline Extended TFR for the year 2010 & -0.161 & 0.0000 & -0.008 & 0.4400 & -0.067 & 0.0000 \\
\hline Proportion of blank votes in 2018 & 4.468 & 0.0000 & -1.162 & 0.0122 & -0.187 & 0.7336 \\
\hline Proportion of null votes in 2018 & -3.512 & 0.0000 & -0.480 & 0.0042 & -0.144 & 0.5088 \\
\hline Population size of the area in 2010 & 0.006 & 0.3821 & -0.010 & 0.0041 & -0.006 & 0.0128 \\
\hline $\begin{array}{l}\text { Proportion of households benefited from } \\
\text { cash transfer program 'Bolsa Familia' in } \\
2010\end{array}$ & & & -1.176 & 0.0000 & -0.745 & 0.0000 \\
\hline $\begin{array}{l}\text { Proportion of women with complete } \\
\text { secondary education in } 2010\end{array}$ & & & -0.378 & 0.0000 & -0.144 & 0.0584 \\
\hline $\begin{array}{l}\text { Proportion of population affiliated to } \\
\text { Pentecostal churches in } 2010\end{array}$ & & & 0.508 & 0.0000 & 0.290 & 0.0001 \\
\hline Old-Age Dependency Ratio in 2010 & & & -0.367 & 0.0089 & -0.369 & 0.0111 \\
\hline Longitude & & & & & -0.007 & 0.0000 \\
\hline Latitude & & & & & -0.001 & 0.5807 \\
\hline $\mathbf{R}^{2}$ & \multicolumn{2}{|c|}{0.40} & \multicolumn{2}{|c|}{0.88} & & \\
\hline
\end{tabular}

Model 1: TFR and population control variables (general controls).

Model 2: general controls + socio-demographic controls.

Model 3: spatial simultaneous autoregressive error model estimation, model 2 controls + spatial controls (large and small scale controls). Spatial autocorrelation test -195.13 , p-value $<0.00000$.

Note: criteria of variables selection is based of Variance Inflation Factor.

\section{Conclusion/Discussion}

In this work, we sought to understand if the actual polarized political scenario in Brazil could be associated with distinguished reproductive levels, measured in small areas of the country, giving an especial attention the correlation between the percentage share of Bolsonaro electorate and TFRs across Brazilian microregions. The reasons for this choice are attached to the conservative and profamily discourse of the now president, which may be associated with large family sizes. However, to the contrary of what we first hypothesize, votes in Bolsonaro did not associate positively with fertility. 
The question that we should ask is what does voting for Bolsonaro mean in a context of family and reproduction? There is one possible explanation to be explored. To some extent, voting for the PSL candidate is associated with an anti-PT electoral behaviour, but it may also indicate people with appreciation to follow traditional gender roles in the household.

According to McDonald's (2000) gender equity theory, countries that follow traditional gender roles inside the household tend to have lower fertility levels than other countries that present more gender equity, inside and outside the family sphere. That is, equal opportunities in the labor market together with equal work distribution between males and females in the household reflect in higher fertility levels. His theory is well supported by empirical evidence of many European countries.

McDonald (2000) compares the fertility levels in Scandinavian countries against countries with more traditional family oriented roles in South Europe. In these last countries, the conciliation of family and work is more problematic in general, and that results in lower fertility levels as consequence. In the case of votes for Bolsonaro, a similar history can be told. More than just a reflection of socioeconomic differences, the lack of gender equity inside families (commonly not advocated by the president) and no states support to reduce women double burden work can be translated into couple choices for a smaller number of children.

Of course that further research is required to understand how this conservative or traditional family values present in Bolsonaro electorate interacts with policies of labour-market flexibility, social security and individual welfare, gender and economic equality, human capital and social/family policy. It is also important to mention that all our interpretations are restricted to aggregate levels associations. This limitation warns us to avoid the "ecological correlation" fallacy, or the extrapolation of correlations measured at the aggregate level to the level of individuals.

\section{References}

Almeida, R. (2019). Bolsonaro presidente: Conservadorismo, Evangelismo e a crise Brasileira. Novos estudos CEBRAP, 38(1), 185-213. https://doi.org/10.25091/s01013300201900010010.

Beaujouan, É., Sobotka, T., Brzozowska, Z.; Neels, K. (2013). Education and sex differences in intended family size in Europe, 1990s and 2000s. Paper presents at conference Changing families and fertility choices. Oslo, 6-7 June.

Berquó, E.; Cavenaghi, S. (2014). Tendências dos diferenciais educacionais e econômicos da fecundidade no Brasil entre 2000 e 2010. Paper presented at Encontro Nacional de Estudos Populacionais 19, 2014, São Pedro, SP. 
Chagas-Bastos, Fabrício H.. (2019). Political Realignment in Brazil: Jair Bolsonaro and the Right Turn. Revista de Estudios Sociales, (69), 92-100. https://dx.doi.org/10.7440/res69.2019.08

Dias, BC (2019). Notícias Falsas e Democracia. Bolsonaro e o Whatsapp nas eleições de 2018. Universidade de São Paulo.

Instituto Brasileiro de Geografia e Estatística (IBGE). 2019. "Pesquisa Nacional por Amostra de Domicílios (PNAD) Contínua; Principais resultados: Janeiro 2019." https://www.ibge.gov.br/estatisticas/sociais/trabalho/9171-pesquisa-nacional-por-amostra-dedomicilios-continua-mensal.html?edicao $=23859 \& \mathrm{t}=$ destaques

Instituto de Pesquisa Econômica Aplicada (Ipea) \& Fórum Brasileiro de Segurança Pública (FBSP). 2018. Atlas da Violência 2018. Rio de Janeiro: Ipea.

IPEADATA (2020). http://www.ipeadata.gov.br/Default.aspx.

Hauer, M., \& Schmertmann, C. (2018). Population pyramids yield accurate estimates of total fertility rates. https://doi.org/10.1007/s13524-019-00842-x

Hauer ME, Schmertmann CP. Population Pyramids Yield Accurate Estimates of Total Fertility Rates. Demography. 2020 Feb;57(1):221-241. doi: 10.1007/s13524-019-00842-x. PMID: 31994021.

Hunter, Wendy, and Timothy J. Power. "Bolsonaro and Brazil's Illiberal Backlash." Journal of Democracy 30, no. 1 (2019): 68-82.

Lesthaeghe R. The decline of Belgian fertility, 1800-1970. Princeton University Press; 1977.

Lesthaeghe R, Neidert L (2009) US Presidential elections and the spatial pattern of theAmerican second demographic transition. Popul Dev Rev. 35(2):391-400.

Lima EEC (2010). Voto e fecundidade no Brasil: o efeito do processo eleitoral durante o regime militar sobre a mudança de comportamento reprodutivo brasileiro. Tese de doutoramento. Centro de Desenvolvimento e Planejamento Regional da Faculdade de Ciências Econômicas da Universidade Federal de Minas Gerais.

Lima, EEC; da Silva, JHCM \& Skirbekk V. Cohort Fertility Trends and Religion Affiliation in Latin America: A Glimpse Through Time. Journal of Religion and Demography, 2019.

Potter JE, Schmertmann CP, Cavenaghi SM. Fertility and development: Evidence from Brazil. Demography. 2002;39:739-761. 